\begin{tabular}{|c|c|}
\hline 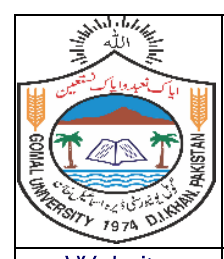 & 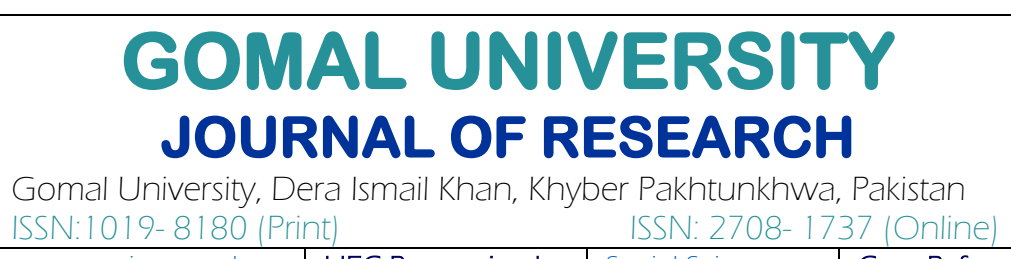 \\
\hline
\end{tabular}

\title{
A STRATEGIC PUZZLE OF SAUDI-IRAN STRIFE AND FOREIGN POLICY CHOICES OF PAKISTAN (2013-18)
}

\author{
Yeldaiz Fatima Shah', Muhammad Adnan Aslam² \& Ghulam Mustafa ${ }^{3}$ \\ 'Department of Pakistan Studies, GC Women University Faisalabad, Punjab, Pakistan \\ 2Department of Political Science and International Relations, GC University, Faisalabad, Pakistan \\ ${ }^{3}$ Department of Political Science and International Relations, GC University, Faisalabad, Pakistan
}

\begin{tabular}{|c|c|}
\hline KEYWORDS & $\overline{A B S T R A C T}$ \\
\hline $\begin{array}{l}\text { Foreign Policy, Triang } \\
\text { Relations, Middle East } \\
\text { Politics, Iran-Saudi } \\
\text { Rivalry }\end{array}$ & \multirow{3}{*}{ 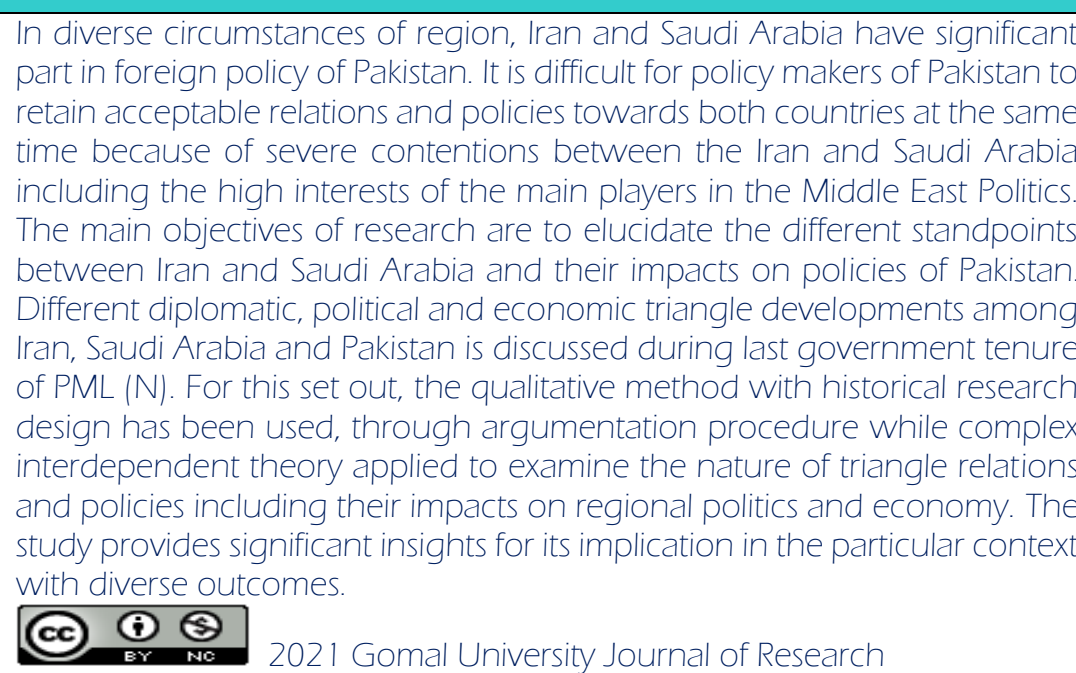 } \\
\hline Article History & \\
\hline $\begin{array}{l}\text { Date of Submission: } \\
\text { 25-03-2021 } \\
\text { Date of Acceptance: } \\
\text { 18-06-2021 } \\
\text { Date of Publication: } \\
\text { 30-06-2021 }\end{array}$ & \\
\hline Corresponding Author & Ghulam Mustafa: ghulammustafa@gcuf.edu.pk \\
\hline $\mathrm{DOI}$ & https://doi.org/10.51380/gujr-37-02-07 \\
\hline
\end{tabular}

\section{INTRODUCTION}

Dynamic foreign policy of Pakistan has always embroidered in the regional and world politics. Good relations towards the Middle East countries have significant part of the foreign policy of Pakistan. Pakistan has better diplomatic, commercial and trade links with the Iran and Saudi Arabia and these countries are maintaining prominent position in regional politics. Policies of Pakistan towards these countries remain different in the different regional scenario. Although Pakistan always wishes to maintain the healthy relations with both Muslim nations yet due to dissimilar religious approaches and the patchy political scenario of the region, sometimes their relations fell in sour and their policies shift in pessimistic dimension. Arab region has divided 
into two major blocs, due to Influence of the major powers and their interests in Middle East politics while Iran and Saudi Arabia have been facing serious security challenges since the last decades. Both Iran and Saudi Arabia are increasing severe tensions and proxy war due to the ideological and economic competition in regional and international scenario (Jaffrelot, 2018). Pakistan in this condition is trying to maintain the coherent constructive policies towards said countries.

PML (N) made government in 2013, on early days' relations of Pakistan towards Saudi Arabia and Iran were in normal conditions but as out broke the civil war in Yemen and Syrian in 2015, Iran and KSA both were expecting to get the visible favor from the Pakistan. In these critical circumstances, Pakistan adopted a neutral policy for Middle East region for balancing relations towards Iran and Saudi Arabia. In January 2016, Prime Minister of Pakistan and chief of army staff visited Iran and Saudi Arabia respectively for minimizing tension between both countries and offered to play a mediating role in peace process of Middle East region. In this connection, Pakistan offered to the government of Iran and Saudi Arabia to make investment in economic corridor which would beneficial for the both countries in trade and investment point of view. Pakistan bilateral trade with the Iran during PML (N) era reached nearly fifty million US dollar only through Tafton border, while overall bilateral trade between both countries was 1.4 billion US dollars annually in different sectors under the severe international economic restrictions on Iran. On the other hands, the bilateral trade between Pakistan and Saudi Arabia during the PML (N) era had reached eleven billion US dollars annually in the different sectors (Keynoush, 2019).

Research work is historical base and it is examining the political, economic and sectarian issue that have had effected policies of Iran, Saudi Arabia and Pakistan respectively, while research elucidates the role of external players in Middle East and South Asia and their brunt on the policies of major actors of region critically. Research is analyzing through the historical mirror, while how political and economic Policies of Pakistan divert as relations misbalance between Iran and Saudi Arabia. The research examines, how the triangle relations among Iran, Saudi Arabia and Pakistan as changes policies of one country conversely reflective effects on policies and actions of other two countries. Qualitative method of research is used to scrutinize triangle policies and relations through the comparison and complex interdependence, while historical research design is analyzing the past events and develops the present concept and conclusion. The Research work reveals the challenges and issues that determine the boundaries of policies among three countries and their future impacts on the regional politics including the triangle relations.

\section{LITERATURE REVIEW}

The book is covering the main reasons behind the rivalry between Saudi Arabia and Iran since centuries and how it destroyed peace of region. Banafshehs Keynoush has covered transitional complexity in relations that are connecting between both main powers of region. The research work is ingraining the reasons of extreme values between Iran and Saudi Arabia on ideological, political and economic bases and their impacts on regional politics and economy. The author highlights the nature of diverse bilateral relations how to effect cross regional economic and political settings (Keynoush, 2019). Kainikara has categorically covered the events of Middle East and South Asian countries Different events that have contemporary to the short, mid and long term effects on regional and inter regional politics and economy. The author has covered 
historically different situations and events of the region in which how Iran, Pakistan and Saudi Arabia played counter role according to objectives, while author reveals how actions directly affect regional political and economic relations. The author is trying to prove that Asia is focus for world and any change in region direct effect on politics and economy of the world (Kainikara, 2017).

Huma Yousif in this study has defined the foreign policy of Pakistan towards eastern and north western neighbors. Research paper highlights the reasons behind the involvement and support of NATO in Afghanistan, while she has elaborated the stance and actions of the administration of Pakistan on Yemen, Syria and Iraq crisis. She has analyzed position of Pakistan in diverse relations between Saudi Arabia and Iran and also has covered economic and Political disputes among the countries of Gulf Cooperation Council. Triangle approach among Iran, Saudi Arabia and Pakistan including their internal security situation has also been discussed in this paper (Yusuf, 2017). This Article has highlighted the impacts of sectarianism and clashes between Sunni and Shi'a tendencies in Middle East and South Asian Muslim countries. The Author focuses to identify the roots which are main hurdle for peace and prosperity in Middle East. Joshi has thrown light on current issues especially role and position of Iran and Saudi Arabia in the internal matters of the most of Middle East countries under the hand of external players to seek their objectives. Research reveals the policies of Pakistan in PML (N) government, how its policies make neutral position of Pakistan between the two rivals in the Arab region (Joshi, 2016).

\section{Theoretical Framework}

The complex interdependence theory was propounded by and Joseph in their book "Power and Interdependence: World Politics in Transition". Keohone and Nye stated that "State and their serendipities are entangled fixed simultaneously" (Keohane \& Nye, 1977). They accent that employ of the military force and balance of power are reducing while the transnational and complex interdependent links has increased amid state and societies for achieving well defined objectives on economic, cultural, social and Political level. Keohone and Nye distinguish interdependence and dependence in scrutinizing role of power in politics and ties among global and regional actors. Situation of dependence indicates an actor or state directly influence from outer forces, most considerably define Interdependence, transnational actors reciprocally cooperate and competitions with each other for common interest and goals. In the context of theory, triangle relations of Iran, Saudi Arabia and Pakistan as changes the policies of one country conversely reflective effects on policies and actions of other two countries. Interdependence is not only the mutual cooperation among these actors but it is interaction of each other in different fields and areas even in politics and economic matter of conflicts. Purpose of research is to interpret upcoming options for Pakistan's foreign policy towards Iran and Saudi Arabia in terms of considerate through examine the relations and policies of Pakistan towards these countries. It historically covers diverse events regarding policies and relations of Pakistan towards Iran and KSA.

\section{RESEARCH METHODOLOGY}

The research historically interprets nature of triangle relations in given time frame (2013-18). Research work analyses sectarianism and foreign elements how to play influential role during the formation and execution of triangle political, economic and diplomatic policies from each side. An anti-terrorism waves and direct involvement of main powers in Middle East politics 
how is effecting triangle policies and relations of Iran, Saudi Arabia and Pakistan on regional and inter-regional settings. It highlights the position of Pakistan in the presence of US forces in Afghanistan and its effects to balance relations of Pakistan towards Iran and Saudi Arabia. Qualitative Method is used to historically define the triangle relations and policies among Iran, Saudi Arabia and Pakistan in political, diplomatic and economic perspective. Research design is used to examine complex interdependent relations historically, while it comparatively analysis policies of government of PML (N) towards Iran and Saudi Arabia separately. By using content analysis methodology secondary data is used, based on books, articles and government published record.

\section{ANALYSIS \& DISCUSSIONS}

Foreign policy of any country has great influenced from internal and external determinants. It bases on the ideology, geo-politics, economy, political system, national interests, defense and security. Pakistan and Iran both facing internal and external challenges since 9/11 incident. Pakistan started operation against Taliban and Al-Qaida in Afghanistan with assistance of NATO forces and Pakistani society was facing worse law and order situation while Iran was on other side facing severe economic sanctions and cross border sectarianism challenges. Daily bomb blasts in Pakistan on public places were common; economy of Pakistan was standing at worse ebb and foreign direct investment at below level. Local Industry was in crisis due to short fall of electricity.

\section{Diplomatic \& Political Bilateral Affairs During PML (N) Era}

PML (N) took over the government on June 2013 with replacement of Pakistan People Party, while on other side in Iran Hassan Ruhani had become a President after two consecutive terms of President Ahmadinejad. The Prime Minister Mian Nawaz Sharif in his first speech after took oath, he was stressing to maintain good relations with the neighboring countries. But Iranian think tanks considered, Sharif's family was maintaining good relations with Saudi royal family since the last decade so it would be difficult task to preserve the healthy bilateral relations with Pakistan that Iran had with last government of PPP (Aslan, 2017). Pakistan and Kingdom of Saudi Arabia (KSA) was continuing good relations since decades due to the mutual economic interests, while Iran was maintaining indulge relations with India in sense of largest economic market in Asia. A state commotion in Afghanistan, Iran was making better strategic relations towards India, while Pakistan policy was assimilating with Saudi Arabia and US (Karim 2015). Pakistan and Iran were treating Taliban for their own ends and external actors were scoring their benefits with the help of both countries in gulf region. The biggest challenge for Pakistan was making equilibrium its policies towards both rivalry countries on the Issue of Yemen and Syria.

Saudi Arabia requested to Pakistan to send the troops for its help against Houdise militants. Pakistan took clear stance that it would not take part of any venture that was not relating to regional politics. Pakistan in 2013 stood with International community on matter of economic sanctions against Iran under Prime Minister Ship of Nawaz Sharif and it was direct gesture to reshaping policy of Pakistan towards Iran. Prime Minister Nawaz Sharif in May 2014 visited Iran. During his visit he signed nine bilateral collaboration agreements with Iran that removed stain on bilateral relations of both countries. Prime Minister Nawaz Sharif met with Ayatollah Khomeini and President of Iran separately and discussed the ongoing mutual security issues, reconsidering rancid projects and regional stability (Vatanka, 2015). Leadership of both sides 
stressed for enhancing cooperation in political, diplomatic, strategic and economic relations. Pakistan and Iran in this session also signed bilateral agreements on collective enhance border security and counter terrorism. Tehran and Islamabad agreed to speed up IP project that was already delayed due to changing regional political scenario. In a same year Pakistan changed its internal security policy and decided to take heavy handed actions impartially against militants groups.

For this purpose, Pakistan started Zarab-e-Azam operation against militant groups throughout county especially in Baluchistan and FATA agencies. Main Purposes of these operations were sweeping out the militants, clear the way of CPEC which would be beneficial project for China, Iran, Afghanistan and Pakistan including it would change the destiny of central Asian States. In 2015, Iran was trying to lose weight from International sanction by using midway possibilities. On other side Obama's administration pulled more pressure on Iran for its nuclear program. Negotiations among Iran and permanent five members of Security Council ( $\mathrm{P}_{5}$ ) country for set a deal which was signed in 14th July 2015 in Vienna Austria. A joint comprehensive plan was made in which most of sanction on Iran was removed and rest of restrictions would be removed after deadline by permanent members of Security Council on Iran. Pakistan showed positive gesture for Iran as Iran signed agreement and both Iran and Pakistan were taking into account that it would escalating economic relations including would helpful to reduce the pressure of US. During this deal process, Saudi Arabia and Israel were despondent with bilateral signatories, both countries were interested to mount more pressure on Iran though P5 countries (Calabrese, 2016).

Foreign minister of Iran, Javad Sharif called on Islamabad in Aug 2015 for enduring mutual projects, regional security and common interests of the neighbors. Two sides felt for making relations more comprehensive and tuning rather than altercation. Both agreed that bifurcation was not suitable and both had already faced many challenges in past to adopt the centrifugal tendencies in bilateral polices. Pakistan and Iran were thinking to extend their IP gas project towards china and government of Pakistan wished to engage Iran in CPEC for collective progress of region (Yusuf, 2017). Civil war in Syria in the end of December 2015 was another challenge for the foreign policy of Pakistan, whether Pakistan would be with Saudi Arabia for set army foot on Syrian crisis or would be remain neutral foreign policy. Pakistan's foreign policy was clear; Pakistan would not the part of this game and would focus upon its internal peace and security. During same year Iran changed its regional policy, it was increasing relations with India, while Tehran was disquieting with the Pak-Saudi strategic and military relations (Aslan, 2017). In this connection, Iran and Saudi Arabia on early 2016 were playing proxy war in the Yemen and Syria that was treacherous condition for Muslim world and especially Middle East. Consequently, Pakistan took incentive and tried to play mediating role between both the rival countries.

Prime Minister Nawaz Sharif and Army Chief Gen Raheel visited Saudi Arabia and Iran in the January 2016. The prime minister and Army chief met with their counterpersons and they tried to motivate them to stop aggressive policies and perused to the de-escalate their tensions with bilateral diplomacy rather than starting war that would create the serious consequences in the region politics (Kainikara, 2017). The relations between Iran and Pakistan reached at turning point in 2016, when an Indian Spy Kulbushan Jadhave was arrested by Pakistani intelligence agencies in Baluchistan. He was illicitly entering in Pakistan through Iranian border on fake 
documents and he involved in the terrorist activates in Pakistan. Pakistan had already claimed that both the Iranian and Indian intelligence agencies were involved to create the tensions in Baluchistan (Keynoush, 2019). During this period, India Raw with the support of the Iranian officials was making unsuccessful attempt for destabilizing south part of Pakistan and it was planning to disturb CPEC project with upheaval separatist movements in Baluchistan. Hassan Ruhani President of Iran made the short transit trip to Pakistan on the way to India in March 2016.

During his bilateral meeting with Pakistan authorities, Pakistan authorities cleared to President of Iran; repeated incidents like wise happened with the assent of Iran in Baluchistan would create difference between neighbors (Erlich, 2018). During his visit, he remained quite due to bulk questions on Indian Spy by media reporters $=$. Pakistan and Iran agreed during Ruhani's visit on free trade through Pak-Iran friendship gate and they agreed to remove some barriers on some trade commodities by Iranian government. Iran was also strengthening economic and strategic dealings with regional Actors. Ties between Iran and Pakistan were significantly moving ups and downs in 2017 due to close relationship of Pakistan government towards Saudi Arabia and inclination of Iran toward India. Pakistani Ex army chief Gen Raheel was appointed first head of the 39 Muslim countries Islamic military alliance (IMA), head office of the IMA was established in Riyadh and it purpose was to stand against terrorism in Muslim countries. Iran was claiming that this alliance was made against Iran and it purely Sunni alliance and it was not hosting the whole Muslim world and it established for the targeting specific community of Muslims as well as it would preserve interests of the particular Sunni Muslim counties (Yusuf, 2017).

Both Iran and Pakistan on early 2018, kept unstable diplomatic relations due to intervening of external factors and political situation of region. In a year of 2018, general elections were held in Pakistan. Most of neighboring countries were waiting which political party would establish new government and in meanwhile PML (N) was focusing on coming elections rest of PTI was optimistic for the results in coming elections. In this connection, in 2018, Donald Trump and its policy makers were exhausted from ongoing war in Afghanistan and they were seeing towards Pakistan, when it would play mediating role for peaceful dialogue between US and Taliban for stable condition in Afghanistan. In these whole circumstances it would be unacceptable for Iran that Taliban could restore government in Afghanistan. On May 2018, US abolished Joint Comprehensive Plan of action (JCPA) with Iran. In this regard, economic re- sanctions were imposed on the Iran by Donald Trump administration and its allies affected the bilateral trade with Iran including it affected bilateral trade between Iran and Pakistan directly (Keynoush, 2019).

\section{Pak-Iran Bilateral Economic \& Trade Relations (2013-18)}

Trade volume between Iran and Pakistan in 2013 was getting low than even from year of 2009. Total bilateral trade was 264 million USD and Pakistan exports were standing on 98 million in 2013 which was comparatively $1 / 4$ from exports from 2009 towards Iran. It all due to security situation on Pak-Iran border including proper measures and were not taken by both governments. Another reason two sides were implementing highly tariff on different commodities (Karim, 2015). Prime Minister of Pakistan Nawaz Sharif visited Iran in May 2014 for cleaning rust on bilateral relations that was halted due to security tensions between both nations. During his visit and met top Iranian leadership and stressed to enhance mutual cooperation in trade and 
economic sectors. Prime Minister of Pakistan spent two days in Tehran and signed eight MOUs and different other protocol agreements with Iranian government that were mostly relating to bilateral trade and border security. Both leaders agreed that they would set up road and railway network and decided, they would construct electric grids stations for augmentation of manufacture industry.

Although both leaders wished to boost up the trade and economic relations including they were enthusiastic to complete the IP project till the end of 2014. Trade graph was low than last fiscal year in a year 2014, total trade between both countries was only 217 million USD. In 2014, Iran was facing severe financial crisis, gross domestic production had decreased; while inflation of Iran reached at $25.7 \%$ in a year of 2011 and it was considering that it would become doubled in 2014 from last few years due to the international economic sanctions on Iran (Vatanka, 2015). Pak-Iran preferential trade agreement that was signed between both countries in 2004, it had almost lost its credibility. Pak-Iran trade volume percentage was $1.54 \%$ before ratified this agreement but after ratification bilateral trade dramatically declined (2012-13) and it stood on $0.38 \%$. During current decade Pakistan's exports were declined from 367 to 85 products only and it was big lose for economy of Pakistan. It created many hurdle for both the countries that may lead to the trade impediment on Iran was reason that disturbed the roots of the exports of Pakistan. Iran was big market of Pakistani mangoes and citrus that has exported in past about thirty thousand tons' mangoes in every year while these could not export after the economic sanctions.

In (2013-2014) Citrus fruit was exported only six thousand tons to Iran, while same condition with Pakistani rice it was exported in 2010 to Iran that worth was 163 million USD and in a year of 2014 its export worth was declined by Pakistan towards Iranian market and it was only 38 million USD. During this period an alternative way was used by the exporters to export rice towards Iran via Dubai due to banking limitations on Iranian government from International Community. Both nations had signed exchanging agreement, in which if Pakistan would export 0.2 million rice to Iran in return Iran would give oil to Pakistan according to the price worth of rice. This barter system agreement could not implement (Rafique, 2017). Agriculture related machinery was considered ideal in Iranian Market but it trade was also affected by international economic sanctions. Joint Trade Committee meeting was held in Tehran in April 2015. A Pakistani delegation which was headed by Khuram Dastgeer Minister of Commerce met with counterpart Mohammad Reza, Minister of Industry, Trade and Mines. In this 7th JTC meeting, officials of both sides were stressing vision of heads of both countries in which would increasing bilateral trade amid Iran and Pakistan from one billon USD to five billion USD in near future.

Khuram Dastgeer articulated his concern during this meeting and highlighted unilateral import bans, import endorsement system and high textile tariffs. Moreover, stated, both trade partners would feasible bilateral trade through preferential trade agreement (PTA) that had bilaterally singed in 2004. During this meeting both sides agreed to revise trade set up and it would formulate for five years facilitation plan for increasing bilateral trade volume between Iran and Pakistan. (Yusuf, 2017). Another MOU was signed by the both countries in March 2016 and it was strategic cooperation plan of bilateral free trade through Pak-Iran free trade agreement (PIFTA) for five years from (2016-21). Many bilateral meetings were held for making plan of action for free trade in which decided the trade commodities and its limits by both countries. 
On early 2017, first meeting of the trade negotiation committee was held in Islamabad. In this meeting Bilal Pasha Joint secretary of finance and trade with his team hosted this meeting, while Mirah Disyadi deputy for Export market development with his delegation came to this meeting from Iran. In this meeting officials from Pakistani side aspired from the government of Pakistan, it should finalize an FTA with Iran that MOU already was signed by both leaders in 2016.

Iranian delegation appreciated the warm attitude from Pakistani side for Pak-Iran free trade agreement (PIFTA) and both sides were agreed to need more discussion on certain changing in this MOU and next meeting would call in Nov 2017 in Tehran for finalizing Margin of preference (MOPL) and broadening of concession lists (BOCL) that would exchange bilaterally before the next meeting would be held in Tehran in November. Besides, during this period both countries were defining bilateral trade volume limits per annum and if it would increase what would be the regularity duty and which measures would be apply to control commodities (Erlich, 2018). In this connection, bilateral trade between both countries was at low level in 2018. According to State bank of Pakistan, Pakistan import commodities from January to November 2018 from Iran that worth were 590 million USD, while authorities of Iran were claiming its trade worth was 860 million USD in first eight months of 2018 which was fifty-five percent more than 2017. In this regard, in a year 2017 total exports from Iran to the Pakistan were 538 million USD approximately and this report was also given by the Mahmood Haji Yousifpur the commerce attaché of Iran in Pakistan but it contradictory from the statistics of State Bank of Pakistan (SBOP).

\section{Figure 1}

Pak-Iran reported Trade volume 2004-2018

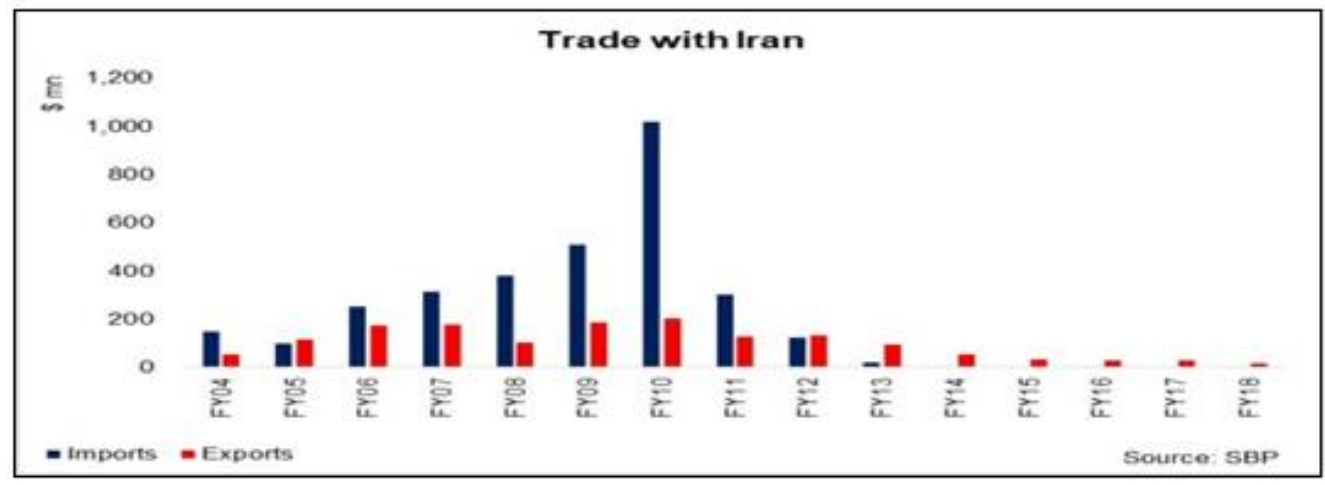

Source: State Bank of Pakistan 2019 (http://www.sbp.org.pk/

\section{Pakistan's Foreign Policy towards Saudi Arabia (2013-18)}

Nawaz Sharif in year 2013 elected Prime minister for the third term in Pakistan. Relations between Pakistan and Saudi Arabia again strategically balanced due to friendly government in Pakistan for KSA. Sharif's family was close personal relations with royal family of KSA and it was supported by royal family during their exile in Gen Musharraf era. Bilateral relations amid Pak-Saudi strengthened and mutual cooperation was increased as PML (N) came into power. Saudi Arabia supported to Pakistani Ambassador Naeem Khan for post of assistant secretary 
general in Asian bench of OIC during PML (N) era. Intentional partnership increased between both countries on international and inter-government level during this period. Bilateral trade and economic relations amid Pakistan and Saudi Arabia were historically in favoring of Saudi Arabia, while the trade from Pakistan during (2013-18) stood in deficit. Pakistan exports from Saudi Arabia stood on oil and lubricant products while KSA was importing from Pakistan mostly food and dairy stuff. While in (2013-18) oil prices per barrel were decreasing in international market and balance of bilateral trade deficit of Pakistan decreased yet Pakistan was importing oil on credit according to sign agreement with Saudi Arabia that was effecting the economy of Pakistan due to heavy international loan. In this connection, the fluctuating loan volume of Pakistan was varying due to varying of dollar in foreign exchange market. Export of Pakistan during the PML (N) era could not enlarged towards the Saudi Arabia which main factor was continuing deficit in trade from Pakistani side. Only in 2017, the trade deficit of Pakistan was nearly 8.7 billion USD that was highly considerable condition for the Saudi Arabia to maintain better relations with the Pakistan for its economic, political and strategic purposes (Jaffrelot, 2018).

\section{Pakistan's Political and Diplomatic Ties towards KSA (2013-18)}

Politically and strategically Pakistan and KSA came closer in early years after came in power of PML (N) government. Leadership of PML (N) was unsurprisingly more prone toward KSA than Iran during second last tenure of government to onwards Musharraf era. The Saudi Arabia was expecting strategic, defense and political ties with Pakistan that would strengthen in the PML government for counter Iran as well as it would helpful to retain visible military support toward KSA ongoing Issues in Middle East (Aslan, 2017). Saudi Arabia was re-shifting its interests towards Asian politics in the stir of budding Iran- America reconciliation on disputes. Saudi Arabian was supporting Pakistan in 2013 for balancing the economic matters and it was ready for supply oil to Pakistan on daffier payment. This gratitude was series for back up support of Pakistan towards KSA, ongoing political and strategic policies in Asia. Crown Prince Selman bin Abdul Aziz visited Pakistan in February 2014; during his visit he met with top political and military leadership of Pakistan. Both sides leadership decided to boost up existing bilateral ties, while they signed consolation ties for peace and stability in gulf region. Moreover, Saudi Arabia would expect support from Pakistan for replacing the government of the President Assad in Syria.

Prior, Pakistan had played neutral role in Syrian crisis but in Joint statement "arrangements of a halfway governing body with full executive powers would authorize it to take over political affairs of Syria" (Qazi, 2013). This statement identified clear influence of KSA for shifting policies of Pakistan towards Middle East. In end of 2014, Yemen crisis was uprising and this upheaval was compelling Hadi's government out of the Yemen in early 2015 with the support of Mr. Saleh Sunni militant group. During early period Housie group was sponsored by KSA, while Zadi Shia group which was pro government, it was sponsored by Iran. Zadi group had involved to destabilizing government of Mr. Salah in the last decade in Yemen. In March 2015, Hadi had fugitive from Yemen after took control of rebellions on capital city Sana and direct confrontation started between Iran and Saudi Arabia on Yemen soil. In meanwhile, both Iran and Saudi Arabia were expecting support from Pakistan in their different perspectives. Saudi family was expecting military support from Pakistan in Yemen crisis and it interested joint venture in Yemen but Saudi's anticipations were water down when Pakistani parliamentarians called joint session and strong-will was adopted that was neutral policy of Pakistan in Yemen 
crisis (Husain, 2016). Pakistan re-assured to Saudi Arabia for its support if it would matter of internal security yet Pakistan would impartial in Middle East for peace and prosperity of the region.

Deputy Crown Prince and Defense Minister Muhammad Bin Salman visited Pakistan in second week of Jan 2016. During his stayed in Pakistan he met top political and military leadership and he discussed ongoing upheaval in Middle East with Pakistani authorities. He separated meeting with Main Nawaz Sharif Prime Minister of Pakistan and chief of army staff General Raheel. The main intention of foreign minister was to get assurance and support from Pakistan for creating Islamic alliance of likeminded countries for coping with terrorism and extremism from Muslim world. Pakistani authorities' reaffirmed support for Anti-terrorism alliance which would led by Saudi Arabia with prop up thirty four countries (Yusuf, 2017). Moreover, both leaders further agreed to enhance mutual cooperation for counter terrorism and root out the mind set of radical activist's groups that were escalating problems for said countries including Middle East region. Factor for re-vital diplomatic ties of Saudi Arabia toward its allied Muslim countries were due to changing scenario and politics of Middle East region and royal family seemed it would offset antagonism of Iran towards KSA. Prime Minister Nawaz Sharif went on 3-day visit in March 2016 to Saudi Arabia accompanied with chief of Army Staff Gen Raheel and Tariq Fatemi assistant to PM Foreign affairs on special invitation of King Salman bin Abdul Aziz.

The invitation was attending closing ceremony of the twenty-four countries Thunder military exercise in which leaders of different countries were called up by Saudi government. Purpose of collective exercise was to improve better and quick actions against terrorism, Pakistani troops were also part of this exercise. Prime Minister of Pakistan and his delegation meeting with Saudi king and during this visit leaders of different Muslim countries formally agreed to establish Anti-terror military alliance that functioned in end of 2016 and Pakistan initially lead this military alliance under financial assistance of Saudi Kingdom (Keynoush, 2019). Pakistan's National Action Plan and its achievements were appreciated by KSA and assured to Pakistan that it would continue support of Pakistan for counter terrorism and extremism. Saudi Arabia would cooperate with Pakistan and would play decisive role for tranquility and stability in region particularly in Afghanistan. Prime Minister of Pakistan and Chief of Army staff visited Saudi Arabia and Iran respectively in early 2016 for diffusing stress amid prominent members of OIC. Pakistan was considering, confrontation between Saudi Arabia and Iran would severe consequences on whole region and Muslim Ummah. Pakistan played mediating diplomacy amid said countries on vague situation which had created in end of 2015 after out broke of Yemen civil war.

\section{Pak-Saudi Bilateral Trade \& Economic Ties During PML (N) Era}

Pakistan was standing 16th trading partner of Saudi Arabia in PML (N) era and total share of bilateral trade had fallen $0.3 \%$ between both countries (Mason, 2015). Pak- Saudi bilateral trade and economic ties were affected by the fallen of oil prices in international market. From (2013-16) bilateral trade volume continuously declined. Although, Mian Nawaz Sharif early days in its last tenure government kept in financial challenges and KSA supported to Pakistan yet international recession directly exaggerated the mutual ties and created negativity between both countries. In a fiscal year (2015-16) exports of Pakistan towards Saudi Kingdom stridently down, while trend of Saudi exports toward Pakistan were declining. Exports of Pakistan toward 
KSA in 2013 were 508.22 million USD that were standing 346.5 million USD in a fiscal year of 2017. On other hand, imports of Pakistan from Saudi Arabia 4010 million USD in 2013, while imports were decreasing continuously about 40\% in 2017 and imports from Saudi Arabia were stating on 2728.7 million USD in a same year. Spur of oil prices were disturbing of joint trade and economy amid both sides. Though, stance of Pakistan in Yemen crisis to adopting neutral policy stained Pak-Saudi economic, political and strategic relations for a short period of time yet circumstances and interdependent policies in regional politics, both countries settled their issues through diplomatically. According to the report of the state bank of Pakistan bilateral trade of both countries was affected by regional tensions and fall prices of oil in international market.

Table 1

Pak-Saudi Bilateral Trade Volume (2013-2018)

\begin{tabular}{lcccc}
\hline Year & $\begin{array}{l}\text { PK exports towards } \\
\text { KSA/Million } \$\end{array}$ & $\begin{array}{l}\text { PK imports from } \\
\text { KSA/Million } \$\end{array}$ & $\begin{array}{l}\text { Trade volume } \\
\text { Million/\$ }\end{array}$ & $\begin{array}{l}\text { Trade } \\
\text { Million } / \$\end{array}$ \\
\hline 2012 & 472.30 & 4285.4 & 4757.7 & -3812.7 \\
2013 & 508.22 & 4010.0 & 4518.22 & -3501.78 \\
2014 & 512.95 & 4232.3 & 4745.25 & -3719.35 \\
2015 & 478.96 & 2462.31 & 2941.27 & -1983.35 \\
2016 & 405.2 & 2030.79 & 2435.81 & -1625.77 \\
2017 & 346.51 & 2728.75 & 3075.26 & -2382.24 \\
\hline 2018 & 404.34 & 2522.13 & 2926.47 & -2117.79
\end{tabular}

Source: State Bank of Pakistan SBP 2018 (http://www.sbp.org.pk/)

Pakistan's exports towards KSA was decreasing 100 million USD annually in last five years from (2013-18) that were indicating no serious economic initiatives were taken by both the authorities (Jaffrelot, 2018). In 2018 Pak- Saudi PTA on vision of Crown prince Muhammad Bin Selman 2030 for increasing bilateral trade and linking Saudi market with three major continents but preferential trade agreement could not enlarge bilateral trade among Pakistan and Saudi Arabia. Top exports of Pakistan towards KSA were the rice, textile garments and fertilizer which were declined in last five years. In 2017, statistics had identified the decreasing ratio of Pakistani exports in KSA markets; rice export was decreased from $8.46 \%$ to $6.11 \%$ of entire importing share of rice in Saudi Arabia including Pakistan and rest of other world. Food stuff items like dairy, vegetables, meat and daily used grocery share of Pakistan in KSA market was also falling $68.31 \%$, semi textile \& garments share was vaguely decreased $56.13 \%$ which was 57.68\% in 2016 fiscal year, while 50\% share of Imports from KSA in Pakistan were Oil and Oil related synthetics products in 2018 that was congregating the energy and industry needs of Pakistan.

Last five years of PML(N) exports of Pakistan toward Saudi Arabia were relatively fluctuating and it could not be congregating, while during these five years' other Asian countries like China, India, Vietnam and Thailand were increasing their exporting share in Saudi Arabian Market randomly. Only in Rice, Thailand and India were incessantly increasing share in Saudi Arabian market. KSA currently third biggest importer of rice in world while Pakistan was third exporter of rice in 2014 towards Saudi Arabia and Pakistan could not maintain its position and it stood among $5^{\text {th }}$ exporting wholly milled rice towards Saudi Arabia in a fiscal year of 2017. Pakistani basmati \& jasmine rice availability was 96.8 million USD in (2017-18) for export towards Saudi 
Arabian market but government of Pakistan could not take proper measures to meet export competitive index than comparatively other exporting units of rice in rest of world. Pakistan in wider picture in (2013-18) had constrained of its trade due to number of problems in which few were commonly lack of logistic services, cost of electricity, rigid market labor, skeptical food safety standards, multifaceted regulation of duties \& tariffs and lastly lake of infrastructure (Jaffrelot, 2018). Pakistan and Saudi joint minister's commission different meetings were held frequently by the both sides for enhancing bilateral trade and they discussed in every meeting on different plan of actions that would boost trade and economic relations but bilateral trade volume comparatively fall due to uncertain condition of region and high rivalry in International market.

\section{CONCLUSION}

Foreign policy of Pakistan towards Iran and Saudi Arabia changes its directions by changing of governments and unpredictable economic position of country. Continuity of mutual policies is dependent on circumstances of regional politics, interests of the nations and foreign interests towards these nations. Clash of Interests, maintaining of economic hegemony in Middle East and sectarian differences are accountable for severe rivalry between Iran and Saudi Arabia that were big challenges for policy makers of PML (N) government of Pakistan for making acceptable policies and ties towards both rivals. In widespread, policies and relations of Pakistan towards both Iran and Saudi Arabia are separately keep two swords in a one sheath. Since 9/11 South Asia especially Iran, Afghanistan and Pakistan were affected terrorism \& extremism as well as anti-terrorism wave and non-proliferation unsettled issues of Iran with drivers of world also exaggerated the political, economic and strategic policies of Pakistan under a severe pressure of US and Saudi Arabia. Economic growth depend on internal and external security of country, from 2000 to early 2016 Pakistan has faced the internal insecurity and energy crisis. In this connection, Pakistan People's Party in its tenure tried to cope with these issues and uplifting agreements of trade and investments including energy projects with Iran yet most of projects suspended due to International pressure. Consequently, Muslim League Nawaz in early days of its government, policies towards Iran and Saudi Arabia was comparatively highly indulging towards Saudi Arabia, while later on these policies had neutral and quite balanced during Middle East crisis. In this regard, PML (N) adopted impartial policies on the regional enduring tensions and Pakistan decided to focus on its internal matters like security, economy and energy crisis.

\section{REFERENCES}

"http://www.sbp.org.pk/departments/stats/FSA-2014-18.pdf." The State Bank of Pakistan. october 15, 2018. http://www.sbp.org.pk/ (accessed June 18, 2019).

Aslan, O. (2017). "Pakistan: Balancing Between Iran and Saudi Arabia." Al Sharq Forum (Al Sharq Forum) 7 (4) (September 2017): 12-25.

Calabrese, J. (2016). Revolutionary Horizons: Regional Foreign Policy in Post-Khomeini Iran. London: Palgrave Macmillan , 2016.

Erlich, R. (2018). The Iran Agenda Today: The Real Story Inside Iran and What's Wrong with U.S. Policy. London: Taylor \& Francis Group, 2018.

Husain, J. (2016). Pakistan and a World in Disorder: A Grand Strategy for the Twenty-First Century. New York: Palgrave Macmillan, 2016.

Jaffrelot, C. (2018). Pan-Islamic Connections: Transnational Networks Between South Asia and the Gulf. New York: Oxford University Press, 2018. 
Joshi, P. (2016). "Tempering Saudi-Iran rivalry and the role of Pakistan." South Asia Monitor 4, no. 3 (2016): 14-19.

Kainikara, S. (2017). Political Musings: Asia in the Spotlight. Delhi: Vij Books India Private Limited, 2017.

Karim, U. (2015). "Iran-Pakistan Relations: The current State of Affairs." Centre of Iranian Study of Ankra 6, no. 2 (November 2015): 14-22.

Keohane, R., \& Joseph, N. (1977). Power and interdependence: world politics in transition. Michigan city: Little, Brown Press, 1977.

Keynoush, B. (2019). Saudi Arabia and Iran: Friends or Foes? London: Palgrave Macmillan Publishers, 2019.

Mason, R. (2015). Foreign Policy in Iran and Saudi Arabia: Economics and Diplomacy in the Middle East. London : I.B.Tauris Publishers, 2015.

Pasha, S., \& Muneem, A. (2005). Islam in Pakistan's Foreign Policy. New Delhi: Global Media Publications, 2005.

Pattanayak, S. (2011). Iran's Relation With Pakistan: A Strategic Analysis. New Delhi: Vij Books India Pvt Ltd, 2011.

Qazi, S. (2013). The Strategic Posture Review: Pakistan. New York: The World Politics Review, 2013.

Rafique, S. M. (2017). The History Of Pakistan. Lahore: Hadri Press, 2017.

Sattar, A. (2013). Pakistan's Foreign Policy, 1947-2012: A Concise History. Karachi: Oxford University Press, 2013.

Vatanka, A. (2015). Iran and Pakistan: Security, Diplomacy and American Influence. London: I.B. Tauris, 2015.

Yusuf, H. (2019). Pakistan in the Middle East: A Cautious Balance. October 4, 2017. www.thediplomat.com (accessed May 20, 2019). 